\title{
Application for Submission of Research Recommendations and Practice Work Web Based
}

\author{
Shofa Shofiah Hilabi ${ }^{1}$ \\ Information System, Faculty of \\ Engineering and Computer Science \\ Universitas Buana Perjuangan \\ Karawang, Indonesia \\ shofa.hilabi@ubpkarawang.ac.id
}

\author{
Arip Solehudin ${ }^{2}$ \\ Program StudyTeknik \\ InformatikaFakultas Ilmu \\ Komputer, Universitas \\ Singaperbangsa Karawang \\ arip.solehudin@staff.unsika.ac.id
}

\author{
Syahri Susanto ${ }^{3}$ \\ School of oil Technic \\ Balongan Oil and Gas Academy \\ Indramayu, Indonesia \\ syahri28@gmail.com
}

\begin{abstract}
Application Submission of Recommendations for Research and Job Training which is often late hampers students who will carry out Research and Practical Work activities that will be carried out at institutions in Karawang, making students have to spend time visiting the Kesbangpol office where sometimes the completion of the letter is not clear when the completion completed, and also because of the head of the Office's signature problem. The research method used is to use the Waterfall method which in this method includes needs analysis, design, implementation, verification, and maintenance. Therefore it is hoped that after the design and recommendation system of a recommendation letter system / tools proposed by the author, it is useful for efficient time for students who will submit a recommendation letter for research and practical work to agencies in Karawang Regency and students do not have to go directly to the Kesbangpol office. Karawang Regency to submit a recommendation letter
\end{abstract}

Keywoard: Applications, recommendations, research letters, practical work.

\begin{abstract}
Abstrak - Aplikasi Pengajuan Surat Rekomendasi Penelitian dan Kerja Praktek yang sering kali terlambat menghambat mahasiswa yang akan melakukan kegiatan Penelitian dan Kerja Praktek yang akan dilakukan di Instansi yang ada di Karawang, membuat mahasiswa harus menghabiskan waktu untuk mendatangi kantor kesbangpol yang mana kadang penyelesaian surat tersebut tidak jelas penyelesaianya kapan selesai, dan juga karena kendala tandatangan kepala Kantor. Metode penelitian yang digunakan adalah menggunakan metode Waterfall dimana dalam metode ini meliputi analisis kebutuhan, desain, implementasi, verifikasi, dan pemeliharaan. maka dari itu di harapkan setelah di rancangnya dan sistem rekomendasi sebuah sistem/tools surat rekomendasi yang di usulkan oleh penulis, bermanfaat mengefisiensi waktu mahasiswa yang akan mengajukan surat Rekomendasi penelitian dan kerja praktek ke Instansi yang di Kabupaten karawang dan Mahasiswa tidak harus mendatangi langsung kantor Kesbangpol Kabupaten Karawang untuk mengajukan surat rekomendasu.
\end{abstract}

Kata kunci: Aplikasi, Rekomendasi, Surat Penelitian, Kerja Praktek.

\section{INTRODUCTION}

Local government has a function in serving the community in administrative and bureaucratic matters. Local governments have various Regional Work Units (SKPD) that carry out their main tasks for the benefit of the community. Regional Apparatus Work Units (SKPD) are elements of regional government administration that to achieve success need to be supported by excellent planning by the organization's vision and mission [1].

A letter of recommendation is bidding made by a certain leader or official that contains information about a person's situation based on authentic data available because the party concerned has asked for his interest [2].

One of the Karawang Regency Regional Work Units, namely the Office of National Unity and Politics (Kesbangpol) of Karawang Regency has the main task of assisting the Regent in carrying out regional government affairs based on the principle of autonomy, namely in the preparation and implementation of regional policies in the field of National Unity and Politics [3].

The National Unity and Political Agency also have tasks including collecting data on the names of the management structure of the secretariat address for all community organizations, non-governmental organizations located in Karawang Regency and also providing guidance for community organizations, non-governmental organizations in Karawang. 1 (one) year and Kesbangpol always takes action against problems that occur between Ormas and other parties using mediating for the sake of unity and integrity as well as conduciveness.

The National Unity and Political Agency also have a duty to facilitate or provide letters of recommendation/introduction to student activities or institutions that will conduct research or carry out practical work. The recommendation letter will be shown to government agencies in Karawang, which if students or institutions that are going to make a recommendation letter must first come to the Kesbangpol office to find out what

There are only requirements needed to submit a recommendation letter. The process of making a recommendation letter from the Kesbangpol Office is relatively short and easy because there is already a certain format for employees. however, the recommendation letter must be signed by the Head of Kesbangpol Karawang, which sometimes the head of Kesbangpol has duties outside the office so that when asked to sign it is quite difficult to contact and difficult to ask 
for free time to sign recommendation letters that have been submitted by students or institutions. That is to save time, therefore researchers will create a web-based information system which will make it easier for students or institutions that will submit letters of recommendation addressed to government agencies located in Karawang, students or institutions only need to open a website which will later be designed by the author, in submitting a letter of recommendation. If a student/institution is going to submit a recommendation letter, the student/institution must have the requirements needed by Kesbang employees, including, KTP, KTA, a letter from the university, if a web-based information system has been designed, the office of national unity and student politics and institutions is only sufficient. Scanning and entering it into the system that has been designed by the author, then the student who will submit also lists which agency it is intended for, and from what date and until what month the student will conduct research / practical work activities, then if the letter has been approved by the employee a notification will appear in the system, and students just need to print the proposed recommendation letter for submission, to the place of the agency to be examined or to do practical work.

Therefore, the author will design a "Application for Submission of Recommendations for Submission of Research and Job Training Case studies at the Office of National Unity and Politics of Karawang Regency" so that students or institutions that will make recommendation letters do not have to come to the office directly and it is easier and more efficient. time.

\section{METHOD}

The results of this study are using the Waterfall method wherein this method includes needs analysis, design, implementation, verification, and maintenance, producing some of the data needed by the author to design a web-based recommendation letter submission system, all of the research results are obtained by observing. directly at the place of researchers and interviews with several users related to research and data collection to achieve this research [4]. The following is Figure 1. Research flow

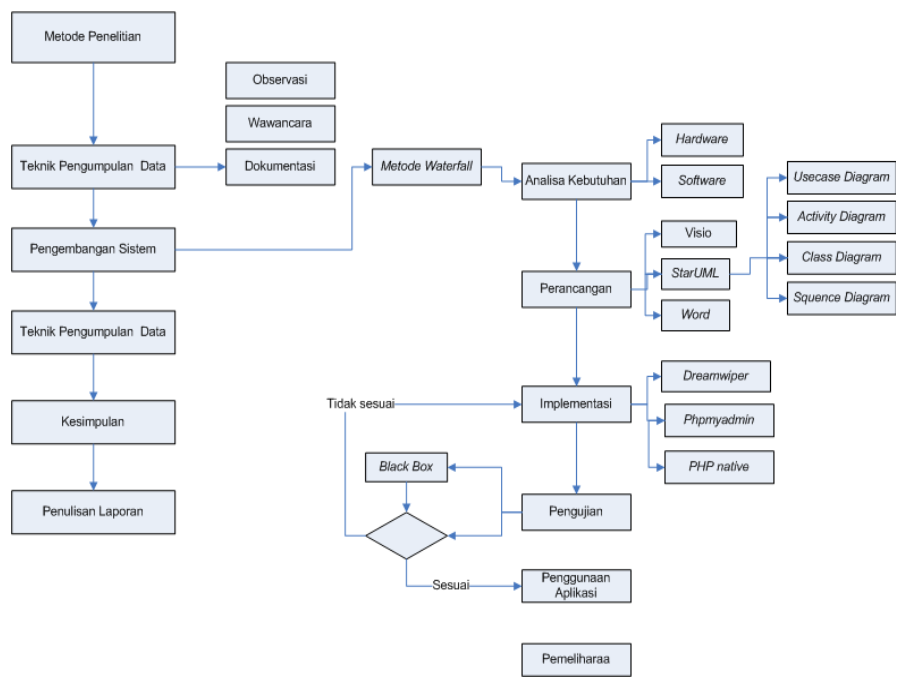

Figure 1. Research flow

Systems Development Methodology

The methodology used in system development for the design and development of this system is the waterfall methodology [5]. The following is Figure 2. the stages of the waterfall methodology

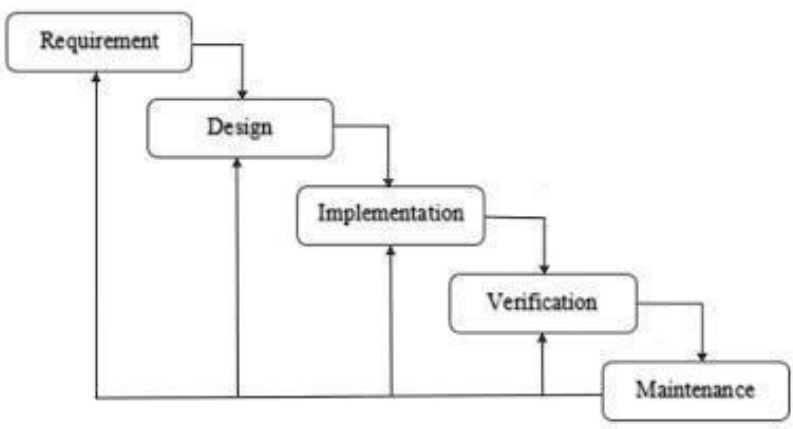

Figure 2.Stages of the waterfall methodology

Several stages of the waterfall methodology, namely:

1. Requirements analysis, collecting the complete needs then analyzed and defined the needs that must be met by the program to be built [6]. Data collection was carried out by the author through observation, interviews and documentation.

2. Design, in this stage the developer will produce an overall system and determine the software flow to a detailed algorithm [5].

3. Implementation is the stage where the entire design is converted into program code. The resulting program code is still in the form of modules that will be integrated into a complete system [7].

4. Integration \& Testing. This stage is carried out by combining modules that have been made and this testing is carried out to find out whether the software made is in accordance with the design and functions of the software [8].

5. Verification is the client or user tests whether the system is approved [9].

6. Operation and Maintenance, namely the installation and repair process of the system as approved [10].

\section{RESULTS AND DISCUSSION}

The application is designed using PHP and Mysql database for data storage. Before entering the coding stage, the design and flow of the proposed system will be made. The following are some of the stages in System And Software Design:

a. Use Case diagram

So to illustrate the system activity that will be designed by the author using modeling using use case diagrams, it is used to find out what functions are in it, and who uses these functions [11]. The following is a Figure 3.Use case is the system recommended by the author. 


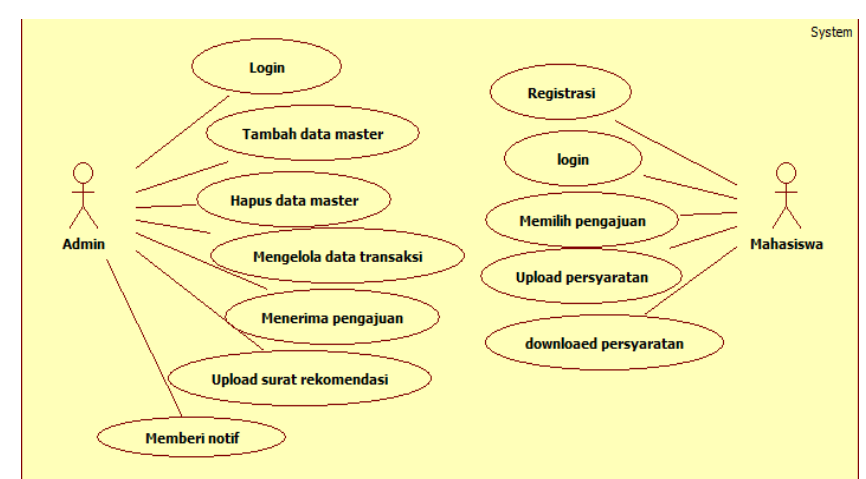

Figure 3. Here is a Use case diagram of a recommended application

\section{A. Activity diagram}

Activity diagrams are used to describe various activity flows in a system that is being designed and how each flow begins [12]. The following is a Figure 4.A diagram of the proposed recommendation system activity.

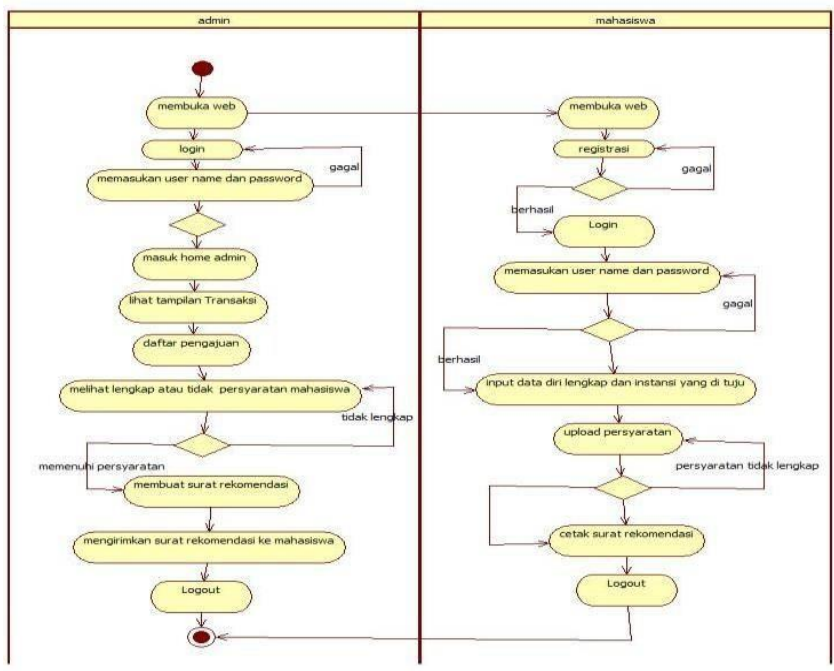

Figure 4.Activity diagram of the proposed recommendation system

B. Class diagram

Class diagrams are used to explain the structure of the system in terms of defining the classes that will be made to build a system [13]. The following is Figure 5. class diagram of the recommendation system.

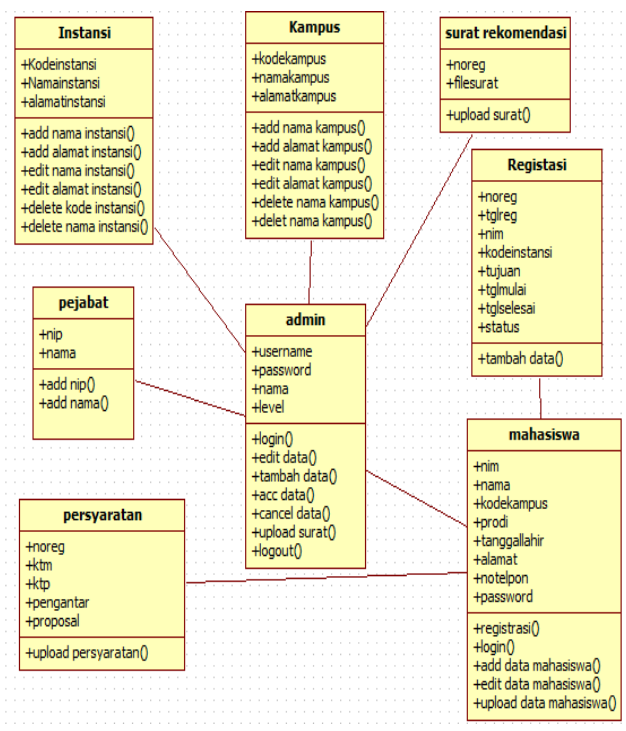

Figure 5. Class diagram of the recommendation system

System Requirements Analysis

System requirements analysis is used to identify new system requirements [14]. System requirements include user needs and admin needs and analysis of platform requirements. Application for submitting letters of recommendation.

1. Admin page
a. Login
b. Agency data
c. University data
d. Official data
e. Transaction data
f. Report data

2. Member page
a. Registration
b. Login
c. Recommended data

Application Implementation

The following is an implementation of the interface on the initial display before entering login [15].

The image below will display a dashboard displaying several menus that can be used by the admin. Then the admin can use the menu as needed by the admin.

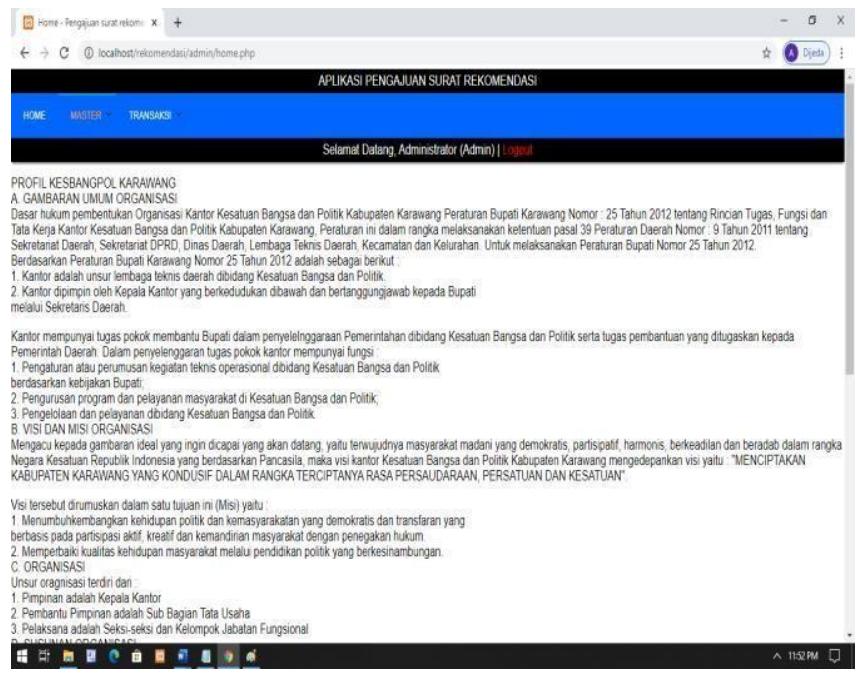

Figure 6. Here is the main admin page

The image below will display a confirmation menu of the recommendation system process used by the admin.

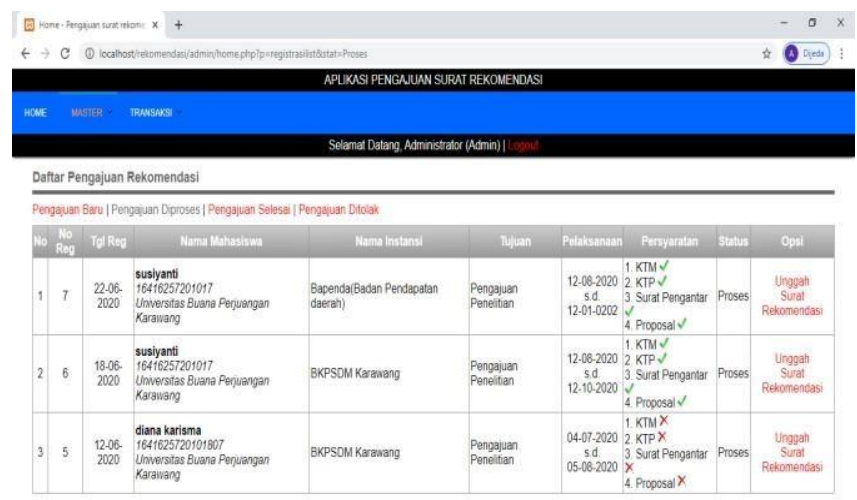


submission

In Figure 7. Below below will display a dashboard displaying several menus that can be used by the user. Then the user can use the menu as needed by the user.

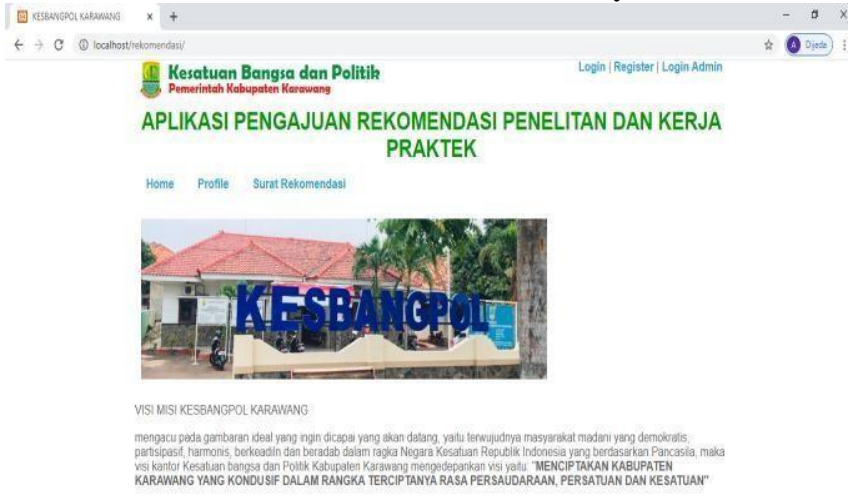

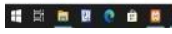

Figure 8 This is the user's main page

The image below displays a dashboard displaying a recommendation menu that can be used by the user in submitting a recommendation letter.

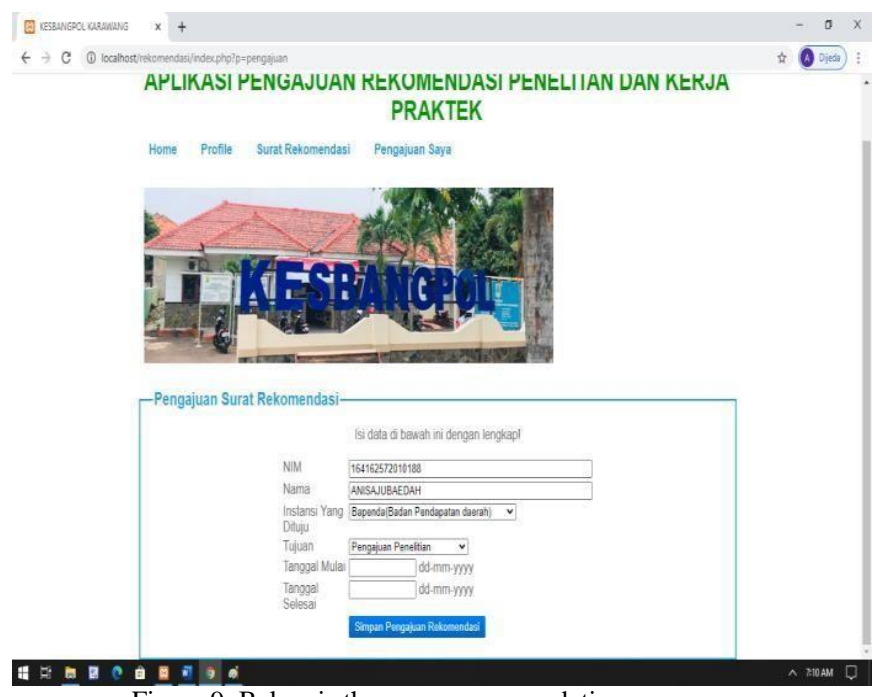

Figure 9 . Below is the user recommendation menu page

\section{CONCLUSION}

Based on the description and overall discussion, the application for submitting research recommendations and practical case study work at the National Unity and Political Office of Karawang Regency, conclusions can be drawn, as follows:

1. To optimize the submission of recommendation letters, this application is made to provide more effective information, and students who submit recommendation letters at Kesbangpol can submit recommendation letters for more than one submission of research recommendation letters or practical work.

2. Creating a web-based application of recommendation letters can make it easier for the admin to verify or validate the submission of recommendation letters so that students do not fill the Kesbangpol office.

\section{DAFTAR PUSTAKA}

[1] C. Nisak, P. Fitri, And A. Kurniawan, "Sistem Pengendalian Intern dalam Pencegahan Fraud Pada Satuan Kerja Perangkat Daerah (Skpd) Pada Kabupaten Bangkalan," Jaffa, 2013.

[2] S. Rachmatullah and A. P. Wijaya, "Rekomendasi Disposisi Surat dengan Metode Naïve Bayes Pada Arsip Surat di Kantor Bakorwil Kabupaten Pamekasan," J. Comput. Inf. Technol., 2019.

[3] Y. Efyanti, "Peran Kesbangpol Linmas Dalam Pembinaan Organisasi Sosial Politik dan Organisasi Kemasyarakatan," Islam. J. Ilmu-Ilmu Keislam., 2019, Doi: 10.32939/Islamika.V18i02.311.

[4] B. Huda, "Sistem Informasi Data Penduduk Berbasis Android dan Web Monitoring Studi Kasus Pemerintah Kota Karawang (Penelitian dilakukan di Kab. Karawang)," Buana Ilmu, 2018, Doi: 10.36805/Bi.V3i1.456.

[5] M. S. Rosa A.S, "Model Waterfall," 2016. 2016.

[6] D. C. P. B. - Stmik Nusa Mandiri Jakarta And I. S. Stmik Nusa Mandiri Jakarta, "Perancangan Sistem Informasi Balai Kesehatan Tni Al Pangkalan Jati Menggunakan Metode Waterfall," Evolusi J. Sains dan Manaj., 2018, Doi:

10.31294/Evolusi.V6i1.3536.

[7] R. Susanto And A. D. Andriana, "Perbandingan Model Waterfall dan Prototyping," Maj. Ilm. Unikom, 2016.

[8] I. Binanto, "Analisa Metode Classic Life Cycle ( Waterfall) Untuk Pengembangan Perangkat Lunak Multimedia," J. Univ. Sanata Dharma Yogyakarta, 2014, Doi: 10.13140/2.1.1586.4968.

[9] A. Abdurrahman And S. Masripah, "Metode Waterfall untuk Sistem Informasi Penjualan," Inf. Syst. Educ. Prof., 2017.

[10] R. Susanto And A. D. Andriana, "Perbandingan Model Waterfall dan Prototyping untuk Pengembangan Sistem Informasi," Maj. Ilm. Unikom, 2016, Doi: 10.34010/Miu.V14i1.174.

[11] B. Priyatna, S. Shofia Hilabi, N. Heryana, and A. Solehudin, "Aplikasi Pengenalan Tarian dan Lagu Tradisional Indonesia Berbasis Multimedia," Systematics, 2019, Doi: 10.35706/Sys.V1i2.1978.

[12] A. L. Hananto and A. R. Priyatna, Bayu, "Android Data Security Using Cryptographic Algorithm Combinations," Int. J. Psychosoc. Rehabil., 2020.

[13] S. Aripiyanto, "Pengembangan Prototipe Sistem Informasi Monitoring Hardware IT Berbasis Web dengan Metode Kano dan Model View Controller: Studi Kasus Pada PT. Kalbe Morinaga Indonesia," Techno Xplore J. Ilmu Komput. Dan Teknol. Inf., 2018, Doi: 10.36805/Technoxplore.V2i2.303.

[14] F. Nugraha, "Analisa dan Perancangan Sistem Informasi Perpustakaan," J. Teknol. Inf. Pendidik. Itp, 2014.

[15] C. A. Pamungkas, "Pengantar dan Implementasi Basis Data," In Pengantar dan Implementasi Basis Data, 2017. 